\title{
Sunrunner: the engineering report
}

\author{
Justin Beres \\ University of Michigan, Ann Arbor, MI 48109-2116 (U.S.A.)
}

\begin{abstract}
In November 1987, the first World Solar Challenge took place, a $3000 \mathrm{~km}$ (1860 miles) transcontinental solar powered vehicle race from Darwin to Adelaide across the Australian Outback. The race, held every three years, featured entries from various countries, including Switzerland, Japan, Australia, and the United States. The winning car, General Motors' Sunraycer, finished $970 \mathrm{~km}$ (600 miles) in front of its nearest competitor. Based on this outstanding performance, General Motors decided not to return to Australia in 1990 , but to instead sponsor a solar car race of its own and send the top three finishers to the international competition. GM Sunrayce USA featured 32 cars from top engineering colleges throughout North America and took place from Florida to Michigan, covering $2660 \mathrm{~km}$ ( 1650 miles) during July 1990.
\end{abstract}

\section{Introduction}

\subsection{The project}

The University of Michigan Solar Car Project almost wholly comprises undergraduate students. Organized into seven teams, students have responsibilities ranging from engineering design to business administration. The project has followed a strict timeline of dates and goals, as the car went from concept to paper to reality in only one year for the GM Sunrayce USA. During the period between the Sunrayce and the 1990 World Solar Challenge, Sunrunner underwent a $27.3 \mathrm{~kg}(60 \mathrm{lb})$ weight reduction, along with small percentage increases in subsystem efficiencies.

\subsection{The car}

Regulations for the aforementioned races allow only sun-derived propulsion energy, with battery storage of this energy. In satisfying these rules through design, Sunrunner's solar cells, singularly referred to as "the array", collect energy which is directed to an electric motor or battery pack. The motor turns a single rear wheel by direct drive reduction. A composite body shell houses the driver, seated in a recumbent nylon seat which is attached to a spaceframe constructed of thin-walled aluminum tubing. The car features a MacPherson strut front suspension, a trailing arm rear suspension, and front wheel steer, with the steering column along the vehicle centerline. Sunrunner is the maximum length and width, but is only $1.27 \mathrm{~m}(4.2 \mathrm{ft})$ tall. It has a wheelbase of $2.43 \mathrm{~m}(95.5 \mathrm{inch})$, and front and rear track 

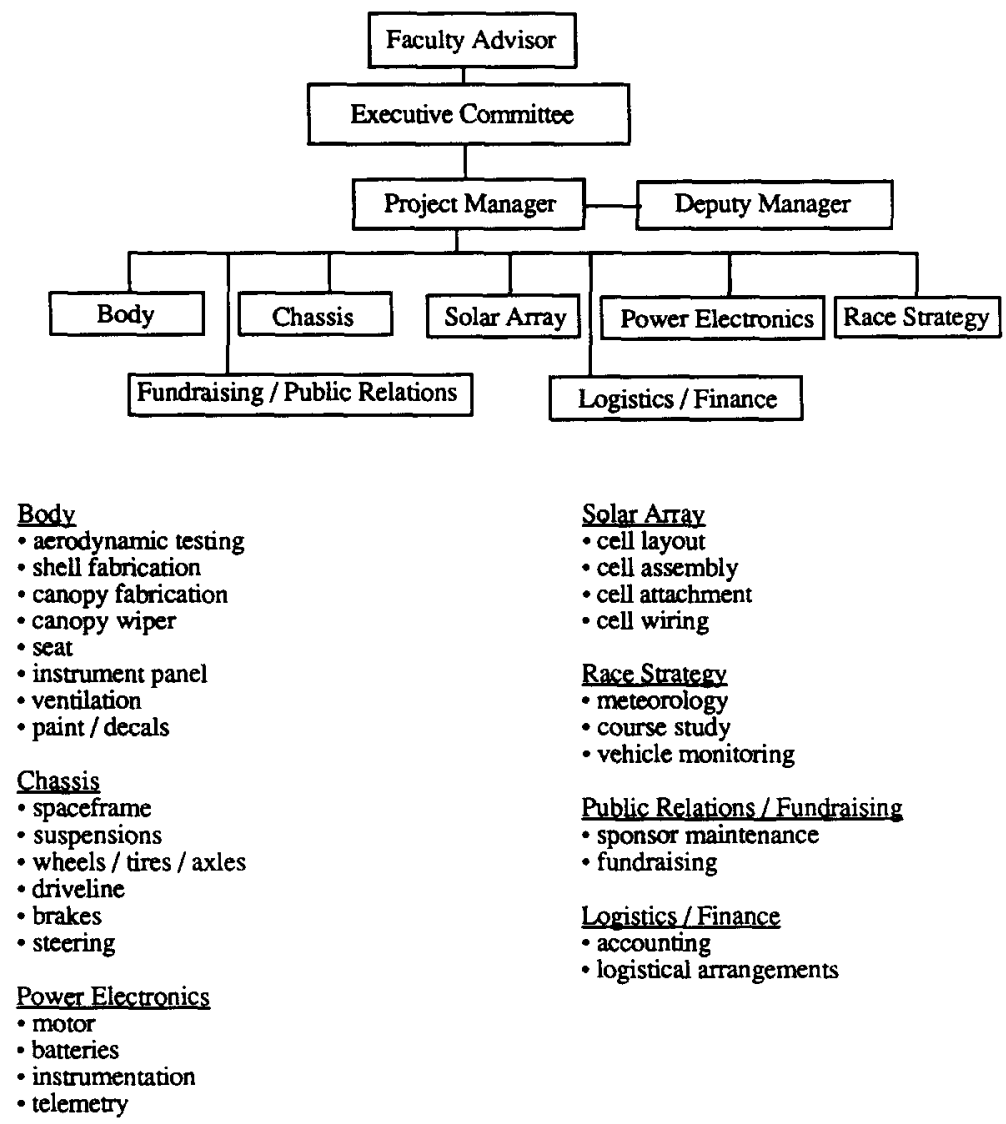

Solar Array

- cell layout

- cell assembly

- cell attachment

- cell wiring

Race Strategy

- meteorology

- course study

- vehicle monitoring

Public Relations / Fundraising

- sponsor maintenance

- fundraising

Logistics / Finance

- accounting

- logistical arrangements

Scheme 1. Team structure and organization.

widths of $1.60 \mathrm{~m}$ (63 inch) and 1.83 (72 inch) respectively, and weighs 232 $\mathrm{kg}(510 \mathrm{lb})$.

\subsection{The design}

In conceptualizing Sunrunner, the objective was to create a vehicle which would obtain as much of the available energy as possible, while expending as little as possible for propulsion. This led to vehicle shape design strategy of maximizing energy accumulation while minimizing resistance forces, considering the expected race conditions of the GM Sunrayce USA. The primary retarding force is aerodynamic drag, which is greater than the rolling resistance. Therefore, the action plan became to achieve maximum solar collection capacity and minimal aerodynamic drag.

This plan, however, spawns a dilemma in solar car design. A car with solar cells laid out on a flat plate, which tilts to be perpendicular to the sun, has the greatest solar gain. However, aerodynamics in this case are quite poor, as flow over a large wetted surface area causes high drag, namely skin friction. In contrast, a car with an aerodynamic teardrop shape complicates 
solar cell arrangement. Cells must be carefully positioned and electronically monitored to insure homogeneous solar loading. The electronic controlling, or "power tracking", inherently creates inefficiency.

The final Sunnunner configuration combined and compromised solar collection and aerodynamics. The shape consisted of three airfoils: the main body and two sidepods. Teardrop shapes maximize aerodynamic efficiency, allowing for attached flow, which reduces form drag, typically the primary contributor of total drag. Placed on the aft two-thirds of the car, 14057 solar cells cover the largest amount of area practical, crudely configuring an upside-down U (Fig. 1). The $8.3 \mathrm{~m}^{2}$ cell area on top is divided into five "facets", or flat lengthwise strips. Facets prevent fracture of rigid cells, by restricting placement on three-dimensional compound curves. The upsidedown $U$ is completed, with $2.4 \mathrm{~m}^{2}$ of area on each sidepod. This arrangement is optimal for sunlight collection, along the south-north route of the Sunrayce and World Solar Challenge, for several reasons. The position of the sun constantly changes, at no time shining directly overhead. Cells on the side of the car are useful during morning and evening hours when the sun radiates at minimal angles to the earth. During cloudy days, sunlight diffuses to the horizon, also coming in at slight angles. Sidepod cells also collect light that has been reflected off the ground.

Once the vehicle shape was finalized a quarter-scale clay model was made. At first, sidepods were symmetric airfoils, in the plan view. Testing in the 5 foot $\times 7$ foot wind tunnel at the University of Michigan offered encouraging results. However, the sidepods were soon made asymmetrical, allowing for more solar cell area in the rear of the car. Also, the pod regions housing the front wheels were widened because they inhibited turning clearance and suspension packaging. Unexpectedly, follow-up wind tunnel testing yielded high drag numbers. Analysis indicated that a downforce was created in the "underbody tunnel" owing to the pressure distribution of the new configuration. The consequence was high negative lift which is quadratically related to drag. The solution to reducing this drag, found through continued wind tunnel testing, was raising the entire car, then pitching the nose of the car upward. This allowed for a ground clearance of $102 \mathrm{~mm}$ (4.0 inch) at the

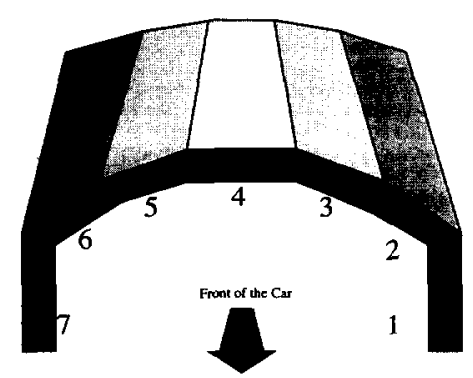

Fig. 1. Configuration of array facets. 
lowest point of the car. Ground clearances at the front and rear axles were $178 \mathrm{~mm}$ (7.0 inch) and $114 \mathrm{~mm}$ (4.5 inch) respectively (Fig.2).

The drag $D$ was measured according to

$D=\frac{1}{2} \rho v^{2} C_{\mathrm{d}} A$

where $D$ is the total drag, $\rho$ the fluid mass density, $v$ the flow velocity, $C_{\mathrm{d}}$ the coefficient of drag, and $A$ the frontal area. It is regulated by only two factors, the coefficient of drag $C_{\mathrm{d}}$ indicating shape, and the frontal area $A$ indicating size. The product $C_{\mathrm{d}} A$ represents the total drag $D$ because the dynamic pressure factor of the equation is composed of variables. Quarterscale wind tunnel results indicated $C_{\mathrm{d}} A=0.15 \mathrm{~m}^{2}\left(1.66 \mathrm{ft}^{2}\right)$, with $C_{\mathrm{d}}=0.091$, based on an area $A=1.70 \mathrm{~m}^{2}\left(18.29 \mathrm{ft}^{2}\right)$. A frontal area scan done on the full-scale car at the General Motors Automotive Wind Tunnel in Warren, MI, verified this area; however, it yielded $C_{\mathrm{d}}=0.120$ with a blockage correction factor of $6 \%$ considered. Flow visualization with smoke showed attached
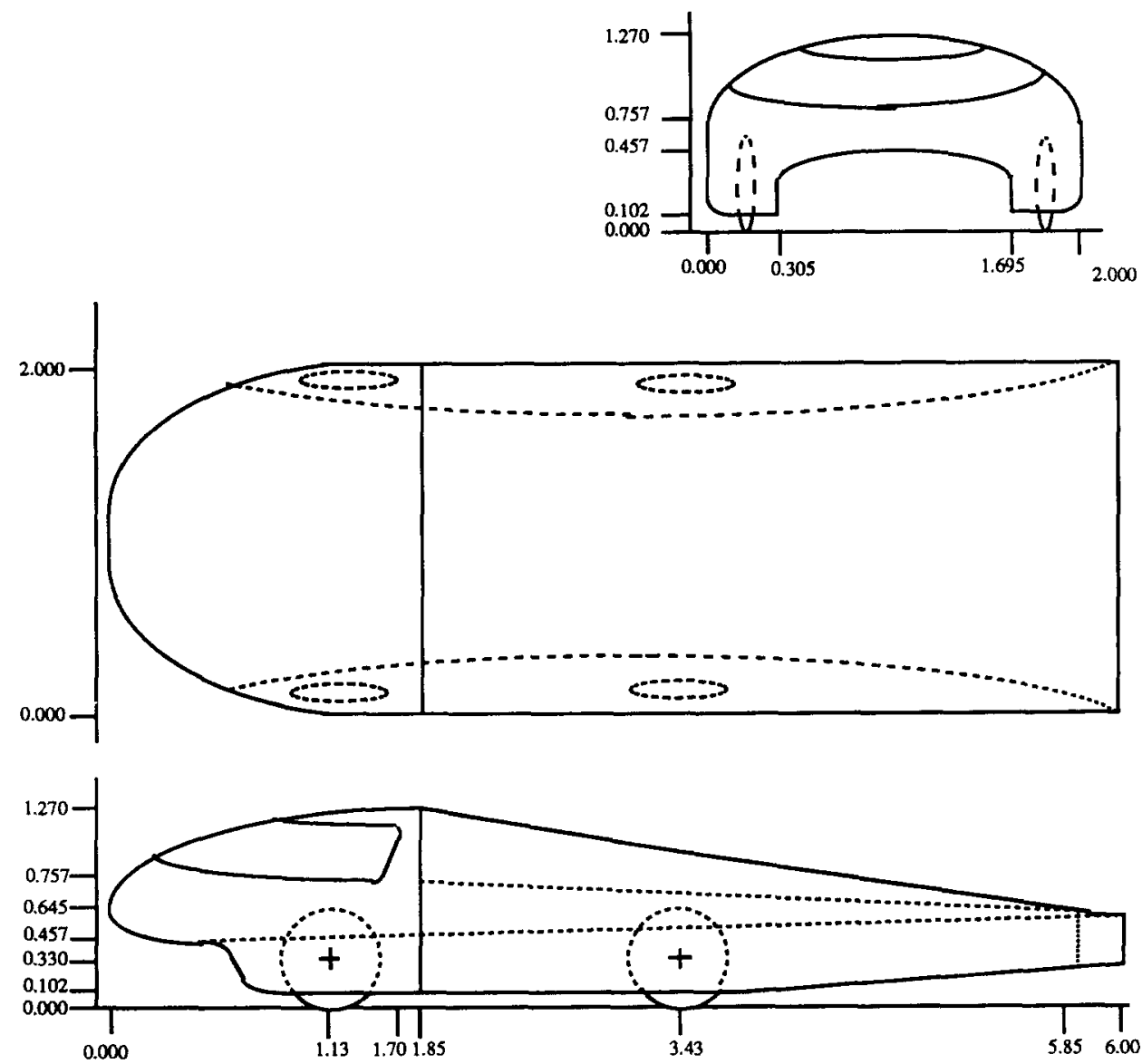

Fig. 2. Drawing of vehicle outline, dimensions in meters. 
flow, yet vortices did exit the rear corners. After minor adjustments were made to wheel openings, $C_{\mathrm{d}}=0.108$ was obtained at zero yaw, producing $C_{\alpha} A=0.18 \mathrm{~m}^{2}\left(1.98 \mathrm{ft}^{2}\right)$. This is about one-third the drag of a conventional automobile.

\section{Body}

\subsection{Exterior}

Once the car was shaped and dimensioned it was divided into sections (Fig. 3). Here, the greatest concern centered around the solar array piece. The car had to be split so that the array could be tilted or removed from the chassis for battery charging and for maintenance before and after each race day. Because of foreseen human handling, the design had to limit the risk of damaging the fragile and costly solar cells. Also, the array had to satisfy the size constraints of the "hypothetical box" rule of GM Sunrayce USA. Other considerations were quick driver exit in order to pass a " 15 second escape" test of the Sunrayce, and accessibility of components for repair.

The body was constructed of composite materials kevlar and Nomex, chosen on the criteria of light weight and ability to absorb large impact energy. Kevlar, a cloth similar to fiberglass, weighs approximately $0.93 \mathrm{~kg}$ $\mathrm{m}^{-2}\left(0.19 \mathrm{lb} \mathrm{ft}^{-2}\right)$ and absorbs $15 \%$ more energy than chromoly steel. Two types were used: 120 , a smooth fine weave used to reduce skin friction drag along the outer surface of the car, and 285, a strong coarse weave for the inner layer. Nomex is a high strength honeycomb, whose density is $28.9 \mathrm{~kg}$ $\mathrm{m}^{-3}\left(1.8 \mathrm{lb} \mathrm{ft}^{-3}\right)$. Its thickness ranged from $9.5 \mathrm{~mm}(0.375 \mathrm{inch})$ to 12.7 $\mathrm{mm}(0.50 \mathrm{inch})$, in between two layers of kevlar, forming a sandwich.

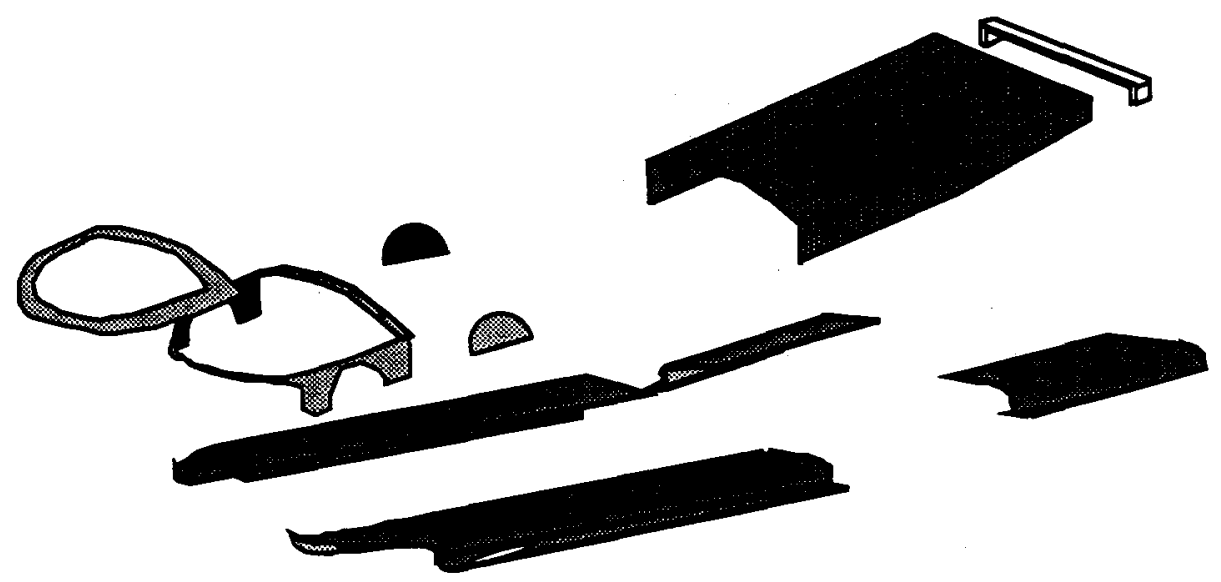

Fig. 3. Drawing of body sectioning. 
Once sectioned, the multi-step process of body fabrication commenced. The quarter-scale clay wind tunnel model was digitized, for which a computer scanned the clay surface reading thousands of three-dimensional data points. The model was then smoothed and made symmetrical from side to side. In the meantime, full-scale armatures were constructed of wood and foam and carefully covered with clay, to ensure adhesion to the foam. When completed, the digitized data were downloaded to a numerical control milling machine where a five-axis cutter carved the clay into the vehicle shape. A facecoat was applied to the clay to produce a smooth surface finish and to seal it. Sheets of fiberglass were laid down, casting female molds. They were removed from armatures and placed into "egg-crates", free-standing supportive wooden structures, allowing them to be level to the ground. These foundations were painstakingly cut to fit exactly the outer curves of the molds. Seams were covered with fiberglass for stability.

Where necessary, sectionlines or partlines were scribed into the molds and multiple coats of three different waxes - found by a trial and error process - were applied to guarantee release of the piece once it was laid up. Kevlar and Nomex were cut to the partlines, the latter forming to curves when persuaded with a heat gun. Materials were then laid down: kevlar/ Nomex/kevlar. Wax was placed at the edges of parts requiring a ridge to join another part. Over it, lips could form.

To ensure proper bonding and to eliminate extra resin from the kevlar, sandwiched parts were vacuum bagged. The three layers were sealed in plastic and attached to a steady suction of $0.5 \mathrm{~atm}$. The part was then heated to $93^{\circ} \mathrm{C}\left(200^{\circ} \mathrm{F}\right)$. After $1 \mathrm{~h}$ the part was removed and pried from the mold with forced air or a knife if necessary.

A structural adhesive was used to bond some pieces permanently. Mounting the chassis spaceframe to the body followed. During the body fabrication process, coordinates of frame attachment points were etched into the molds. In these places, $152.4 \mathrm{~mm} \times 152.4 \mathrm{~mm}(6 \mathrm{inch} \times 6$ inch) squares of Nomex were cut out and replaced with six reinforcement layers of kevlar. Aluminum plates, $3.2 \mathrm{~mm}$ thick $(0.125 \mathrm{inch})$, were glued to the kevlar, then covered with fiberglass. Holes were drilled up through the body into similar plates welded to the frame, and the two were secured with elevator bolts. Quarterturn fasteners were used to attach removable body pieces together.

The canopy of the solar car is likened to a windshield of a conventional auto. Its requirements were minimized weight, good optical quality, abrasion resistance, and light reflection capability for driver comfort. In developing Sunrunner's canopy there were five considerations: material, thickness, forming, tinting, and attaching.

Study of materials led to thermoplasts, namely acrylics and polycarbonates, which could be drape or blow molded. Several tinting options were researched, such as see-through mirror, Scotchtint, metallizing, coloring, and evaporated metal film covering. The final design was a drape-molded, $3.2 \mathrm{~mm}(0.125$ inch) thick, scratch-resistant acrylic, urethaned to the kevlar-Nomex canopy frame. Sputter coated with titanium nitride, it allowed $17 \%$ light transmission. 


\subsection{Interior}

Ergonomics were thoroughly analyzed in the design of Sunrunner's interior with respect to driver packaging, comfort, and safety. More specifically, topics of seating, vision, ventilation, and controls were given attention.

Packaging space was restricted as a result of minimizing frontal area to lessen drag. Initially, gliders and M1 tanks were researched because of their similar seating conditions. The requirement for light weight led to a hammock-style seat design employing a strong stretch-resistant woven mesh material. Weave patterns are stronger than knit because of the bi-directional interlacing of strands. The anti-stretch characteristic prevented sag; an important consideration, because the allotted distance between the bottom of the seat and the inner body surface was a mere $25.4 \mathrm{~mm}$ ( 1 inch).

After the seat was attached to the spaceframe the canopy was designed. Fulfilling vision requirements of GM Sunrayce USA, driver eyes had to be no less than $700 \mathrm{~mm}$ ( $27.6 \mathrm{inch}$ ) off the ground. The driver had to be able to see $10^{\circ}$ above the flat horizon, $90^{\circ}$ from either side of the center, and a spot $8 \mathrm{~m}(26.2 \mathrm{ft})$ in front of the car.

In order to determine the canopy daylight opening, a mock-up of the cockpit was constructed. Here, several drivers sat in the seat while five wooden templates simulating the body shell were placed over them, spaced $200 \mathrm{~mm}$ (7.9 inch) apart, starting from the car's nose. Forward vision was tested by increasing or decreasing the first template height. Side-to-side testing was more arbitrary, as no distance or "point on the ground" rules were specified. Despite this, Sunrunner's canopy offered $180^{\circ}$ of sight latitude.

Rear vision utilized a fiber optics bundle rather than mirrors mounted to the car's exterior which would cause increased drag. On one end, the bundle attached to an eyepiece through which the driver could view images in a $40^{\circ}$ range. An objective lens connected at the other end and was mounted on top of the car, just fore of the solar array, housed in a small aerodynamic fin. The bundle, as thick as a garden hose, was composed of thousands of smooth glass fibers, each independently conducting light by means of multiple

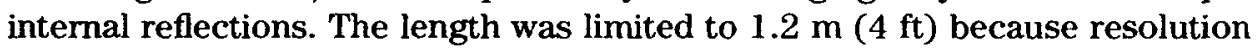
is inversely proportional to length.

Comfort encompassed two considerations: driver overheating and controls accessibility. To investigate fully how heat affects drivers, a test was conducted simulating predicted interior temperatures. Subjects sat in the seat surrounded by two space heaters placed on wooden platforms to the right and left. Blankets were draped over the test templates and cardboard was taped around the back of the spaceframe. All this was done in an attempt to retain as much heat as possible. Wet and dry bulb thermometers were placed inside the cockpit. The steering wheel was wired to a computer on which a driving simulation program was run to occupy drivers during a $90 \mathrm{~min}$ test session. Six times drivers were asked to rate comfort of the neck, back, arms, and thighs, as temperatures reaching $35^{\circ} \mathrm{C}\left(95^{\circ} \mathrm{F}\right)$ were simultaneously noted. Results based on observed reactions as well as comfort ratings and comments from subjects forced adjustments to the cockpit design. 
Regarding the seat, the chosen Lino Mesh allowed for airflow, keeping the driver cool. Search for a nylon mesh material with adequate gaps between the weave for ventilation and high denier, or fineness of thread, for strength, led to consideration of materials such as Cordura, Dymetrol, and Textilene. Upon final positioning, test results indicated that discomfort from body fatigue occurred after about $5 \mathrm{~h}$ : the maximum expected driving time for any person.

In conjunction with the seat and tinted canopy, the ventilation system aided in driver cooling. Mylar ducts running from two inlets on the vehicle nose branched to the driver, motor, motor controller, and batteries. The inlets, $23.2 \mathrm{~cm}^{2}\left(3.6 \mathrm{inch}^{2}\right)$ in cross-sectional area, located in regions of highest pressure as determined by wind tunnel pressure distribution experiments on the quarter-scale model, allowed for an airflow of $140 \mathrm{ft}^{3} \mathrm{~min}^{-1}$. Initially, inlets were placed at the stagnation point of the car. However, fear of destroying the laminar boundary layer led to the final configuration. A fan supplying $35 \mathrm{ft}^{3} \mathrm{~min}^{-1}$ of forced ventilation was placed in the $102 \mathrm{~mm}$ (4 inch) diameter tube ducted to the driver. Forced air was also provided to the motor, controller, and battery pack using $40 \mathrm{ft}^{3} \mathrm{~min}^{-1}$ fans.

Aspects of the car which required monitoring directed design of the instrument panel. Instrumentation included a speedometer, tachometer, battery charge display, and solar array ammeter gauge. The cruise control knob, turn signal knob, forward-reverse switch, fan switch, horn button, and indicator light lamps were controlled manually. Braking and acceleration were operated by foot pedals. Arrangement of the controls was critical, with ease of accessibility the highest priority. Final component placement was achieved after experimentation with various positions.

With regard to safety, the distance from the driver's feet to the nose of the car was over $305 \mathrm{~mm}(1 \mathrm{ft})$, providing crush area in the case of a head-on collision. Head clearance was measured at $102 \mathrm{~mm}$ (4 inch), as the spaceframe extended over the seat, protecting against roll-over conditions. The driver also wore a six-point climbing harness for restraint. The harness's male plugs buckled into female receptacles sewn to the seat.

\section{Solar array}

\subsection{Solar cells}

Four types of cells were considered (listed in increasing order of performance and cost): amorphous silicon, polycrystalline silicon, monocrystalline silicon, and gallium arsenide. Efficiencies are approximately 5\%, $12 \% 17 \%$ and $22 \%$ respectively. The cost of space grade gallium arsenide cells is four times that of space grade monocrystalline cells, which, in turn, cost ten times more than terrestrial and amorphous cells.

\subsection{Array layout}

GM Sunrayce USA regulations dictated that the array fit into a hypothetical volume $4 \mathrm{~m}(13.1 \mathrm{ft})$ by $2 \mathrm{~m}(6.6 \mathrm{ft})$ by $1.6 \mathrm{~m}(5.3 \mathrm{ft})$. Sunrunner's space 
grade monocrystalline cells, supplied by Spectrolab, are $17 \%$ efficient, producing a peak power output of $1400 \mathrm{~W}$.

The array was arranged two ways: into facets, conforming to the vehicle configuration, and into "sections", pertaining to energy collection. The former allows for an airfoil shape, while the latter allows for power maximization using "trackers". Cells connected in series form snake-like lengths called "strings", which, also placed in series, form "modules". Modules connected in parallel were segregated into sections. Sectioning linked the modules on the car with similar three-dimensional orientation, since they experience comparable solar intensity. Theoretically, modules in a section must receive uniform radiation in order to produce the highest output. However, in the case of Sunrunner, owing to time, geometry, and wiring constraints, the sections were exactly facets.

Cells are manufactured to. a voltage specification at a certain temperature - as the ambient temperature increases, the voltage decreases linearly. Tests showed voltages at maximum power points of $0.39 \mathrm{~V}, 0.44 \mathrm{~V}$, and $0.49 \mathrm{~V}$, at $70^{\circ} \mathrm{C}\left(158{ }^{\circ} \mathrm{F}\right), 50^{\circ} \mathrm{C}\left(122^{\circ} \mathrm{F}\right)$, and $28^{\circ} \mathrm{C}\left(82^{\circ} \mathrm{F}\right)$ respectively, per 20 $\mathrm{mm} \times 40 \mathrm{~mm}(0.8 \mathrm{inch} \times 1.6$ inch $)$ cell. At their most efficient point, trackers required $190 \mathrm{~V}$. The array also had to produce a potential above the maximum battery voltage of $136 \mathrm{~V}$, allowing the batteries to charge. Designing for worst case temperature conditions, an average of 380 cells were organized into 15-20 strings which formed modules, offering an operating potential of $190 \mathrm{~V}$ and $280 \mathrm{~mA}$ at $28^{\circ} \mathrm{C}\left(82^{\circ} \mathrm{F}\right)$. Five modules per facet were placed on top of the car, with six on each sidepod.

The lengths of the 676 strings were limited by facet width, cell width \pm 0.50 $\mathrm{mm}(0.020 \mathrm{inch})$, and a physical gap between cells of $1 \mathrm{~mm}(0.040 \mathrm{inch})$. Cells in strings maintain the same current characteristics. The cell with the lowest current limits the output of the entire module as a result of the series connection. Likewise, modules with the lowest voltage output limit the potential going to a tracker. Because horizontal surfaces collect the most sunlight throughout the day, cells with highest currents were placed on top of the car.

\subsection{Array assembly}

The first step in assembling the array was attaching two silver interconnects to the back of each cell. Next, cells were covered with a magnesium fluoride coated antireflective glass, glued with two drops of a silicone adhesive. This not only protected the cells, but also diminished reflected power loss. Cells were cured for $40 \mathrm{~min}$ at $38{ }^{\circ} \mathrm{C}\left(100{ }^{\circ} \mathrm{F}\right)$ and $100 \mathrm{~min}$ at $54{ }^{\circ} \mathrm{C}\left(130^{\circ} \mathrm{F}\right)$. They were then cleaned and soldered in strings, held steady by aluminum CNC-milled jigs. "U-tabs" were added to string ends, over which silver bus strips were soldered, forming modules.

\subsection{Cell matching}

Once soldering was completed, strings were examined on a light bench to match like voltages and to check for defective cells. Modules with equal 
voltages were united to a tracker. Trackers electronically regulate the array output current $I_{\text {array }}$ to produce maximum output power. The "bus voltage" varies constantly. Array power output $P_{\text {out }}$ is the product of the array current and bus voltage,

$P_{\text {out }}=V_{\text {bus }} I_{\text {array }}$

Solar insolation is dependent on time of day and weather. For example, under tree shadow or during cloudy late afternoon, current outputs are lower than at noon on a sunny day. Trackers control the array current and bus voltage, sensing those at "maximum points", offering maximum charging power to the batteries while preventing loss of power through dissipated heat.

The light bench simulated 1 Sun intensity conditions, equalling $100 \mathrm{~m}$ $\mathrm{W} \mathrm{cm}^{-1}$ - the average amount of light reaching the earth at solar noon on a cloudless, $25^{\circ} \mathrm{C}\left(77^{\circ} \mathrm{F}\right)$ day. Here, eight $300 \mathrm{~W}$ light bulbs were attached to chemistry stands, fused to prevent heating up and self-destructing, and continuously cooled by fans. Orientations were adjusted to achieve uniform illumination and temperature. A deviation of $7 \%$ was verified when a reference cell with a known current was moved along the rectangular, 102 $\mathrm{mm} \times 660 \mathrm{~mm}$ ( 4 inch $\times 26$ inch) test area, and an unchanging current output was measured. Each string of cells was placed on the bench, and its characteristics plotted on a type- 575 transistor curve tracer, which is similar to an oscilloscope. From the graph, maximum power points were taken (Fig. 4).

A digital multimeter found open-circuit voltages and short-circuit currents for each string. At air mass (AM) 1.5, per cell, $V_{\mathrm{oc}}=580 \mathrm{mV}$ and $I_{\mathrm{sc}}=292$ $\mathrm{mA}$. From these numbers, efficiencies were calculated:

$\eta_{\text {cell }}=\left[\left(I_{\text {sc }} V_{\text {oc }}\right) /\right.$ Area $\left._{\text {cell }}\right] /($ sun intensity $)$

\subsection{Attachment}

After matching, high bonding double-sided transfer film was used to attach modules to the car's kevlar surface. Gaps between cells were filled

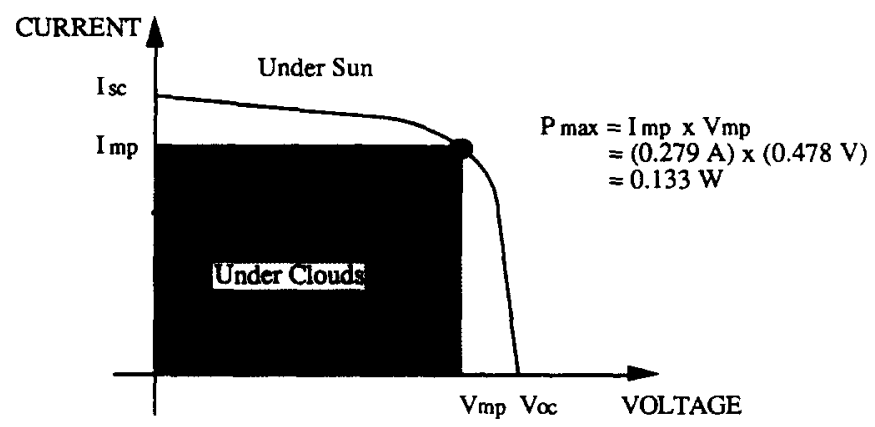

Fig. 4. Current-voltage curve for a solar cell. 


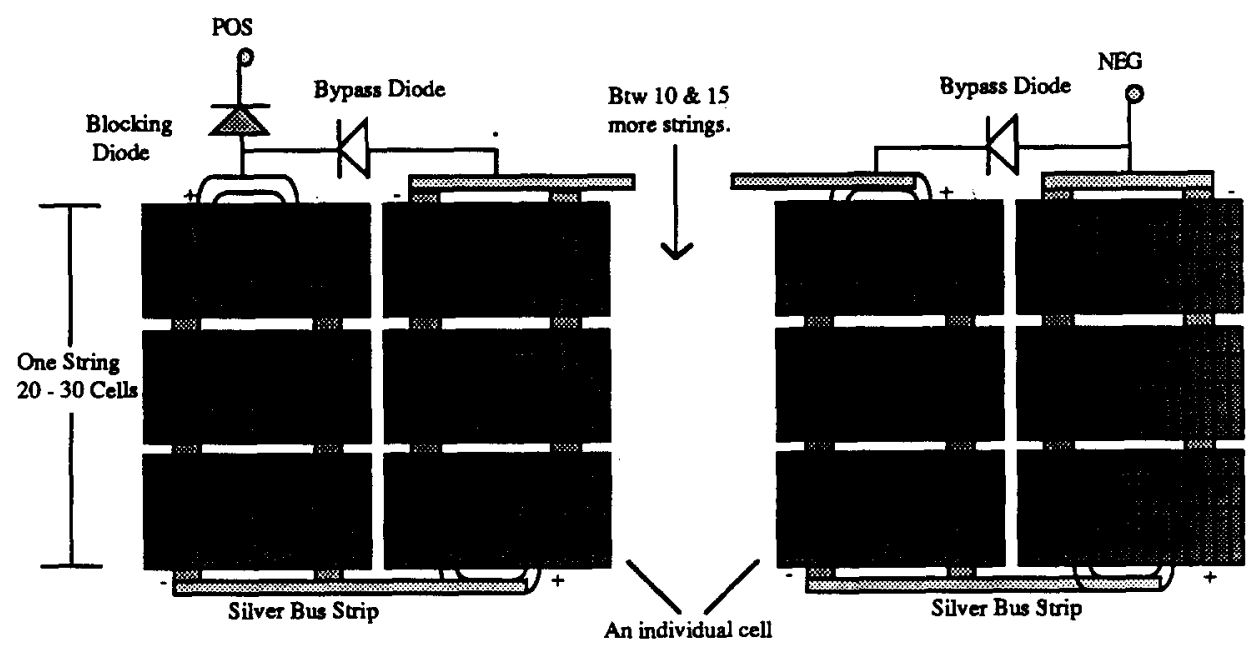

Fig. 5. Diagram showing cell wiring.

with a silicone grout to prevent shorting caused by water seepage and breakage caused by cell expansion at high temperatures. After complications involving controlled fluidity, homogeneous viscosity and curing were resolved, the grout was successfully applied.

\subsection{Wiring}

Modules were joined to power trackers via a "harness" employing 18 gage copper coated silver wire, chosen for its light weight and low resistance per unit length. Its Teflon covering offered advantageous durability and thermal and electrical insulation properties. Maximum operating ratings of $600 \mathrm{~V}$ and $105^{\circ} \mathrm{C}\left(221^{\circ} \mathrm{F}\right)$ were well beyond the application range. An aircraft-type circular plastic pin connector was used to plug the array wiring into the trackers.

In order to scrutinize array performance and troubleshoot difficulties, a power and a ground wire emanated from each module. Limited line lengths were achieved using a computer aided design program. Bypass and blocking diodes were then wired into the array. One blocking, or isolation, diode separated each module preventing a defective or unilluminated module from acting in reverse bias and drawing current from an adjacent module. Bypass, shunt, or shadow, diodes, connected in parallel with strings, are reverse biased when all cells operate properly. If a cell was defective or shadowed, the diode opened alternate routes through which current could flow, avoiding the open circuit (Fig. 5).

\section{Power electronics}

\subsection{Batteries}

Solar energy not used to propel the car directly was reversed in batteries. GM Sunrayce USA rules limited storage capacity to $5 \mathrm{~kW} \mathrm{~h}$ at a $10 \mathrm{~h}$ discharge 
rate, with ventilation of $10 \mathrm{ft}^{3} \mathrm{~min}^{-1}$ taken from and exhausted to the outside of the car.

\subsection{Battery selection and use}

"Specific energy", life expectancy, and cost were considered in the battery selection process. The silver zinc (AgZn) type was chosen over nickel cadmiun (NiCd) and lead acid (Pb-acid) types. AgZn maintain $62 \mathrm{~W} \mathrm{~h} \mathrm{lb} \mathrm{lb}^{-1}$, which is four times the specific energy of the other two types, and also feature the smallest voltage drop during discharge. Each of the $6840 \mathrm{~A} \mathrm{~h}$ cells weighed $0.60 \mathrm{~kg}(1.33 \mathrm{lb})$, and produced a mean operating voltage of $1.55 \mathrm{~V}$, with maximum voltage of $2.05 \mathrm{~V}$.

Battery lifetime is a combination of "cyclic life" and "shelf-life". AgZn batteries are rated for ten "deep discharge cycles" and over 700 "trickle charge cycles". The "wet shelf-life" of the AgZn cells is three to six months, a life span which fit well within Sunrunner requirements.

"Activation" consisted of adding a liquid potassium hydroxide electrolyte to "dry cells" which were then allowed to stand for $48 \mathrm{~h}$, permitting proper bathing of the "separator". Next, cells were fully charged to $2 \mathrm{~V}$, discharged, then charged again.

Typically, charging offers two options: constant potential and constant current. A charging source held at constant potential $V_{s}$, delivers current, until the battery voltage $V_{\text {bus }}$ approaches $V_{\mathrm{s}}$. When $\dot{V}_{\text {bus }}=V_{\mathrm{s}}$, the current stops flowing, and charging terminates. During constant current charging the voltage can float. In this case, overcharging is probable because the current continues to flow even when $V_{\text {bus }}=V_{\max }$. As a result of constantly fluctuating solar array output currents, Sunrunner's batteries were variable current trickle charged, a variation of the second method. The variable current charging was done by the trackers, which in a sense acted as ideal current sources, maximizing power to the batteries by regulating changing array currents and bus voltages (Fig. 6).

\subsection{Motor selection}

The goal in selecting Sunrunner's motor was achieving the highest possible efficiency, with a spatial volume constraint of $178 \mathrm{~mm}$ ( 7 inch) in length by $152 \mathrm{~mm}$ ( 6 inch) in width by $152 \mathrm{~mm}$ ( 6 inch) in height.

Sunrunner's final motor was an a.c. three-phase brushless inductance motor, constructed with Magnaquench III permanent magnets. It was controlled by a pulse-width-modulated (PWM) static inverter, changing direct current voltages from the solar array or batteries to the required alternating current voltages. The PWM frequency was such that it allowed the motor and controller to operate as a system at its highest point of efficiency, with an input power of 900-1100 W (1.21-1.47 hp), offering a peak power output capability of

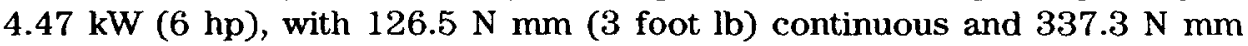
(8 foot $\mathrm{lb}$ ) peak torque. 


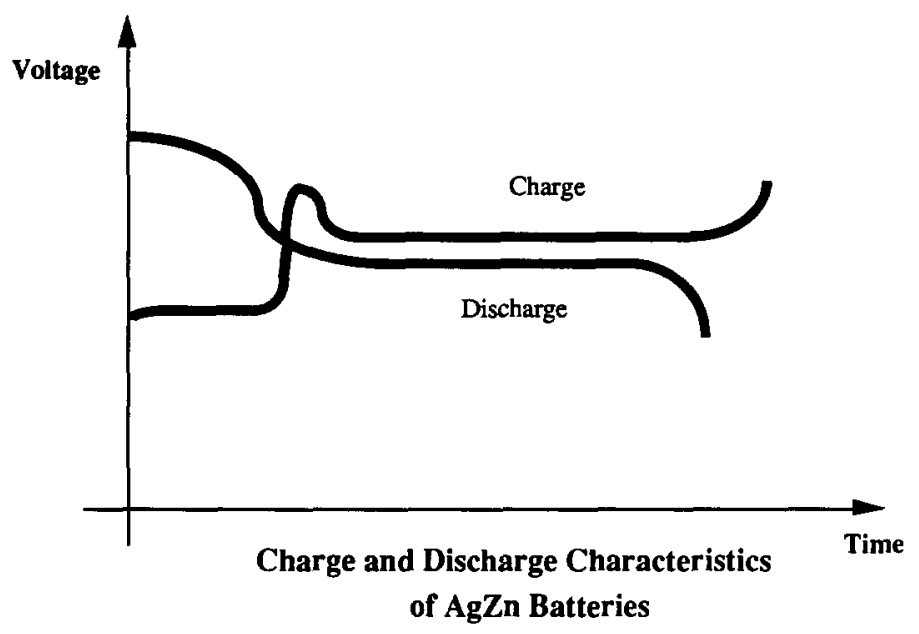

Fig. 6. Charge and discharge characteristics of AgZn batteries.

\subsection{Driveline system}

During the selection process several motors were tested on a dynamometer, including two d.c. brushless designs. Input voltages were kept constant at motor speeds $\omega$ ranging from 3000 to $4500 \mathrm{rev} \mathrm{min}^{-1}$, in increments of $500 \mathrm{rev} \min ^{-1}$. Input currents were measured to find the total input power $P_{\text {in }}$. Also measured was the motor torque $\tau_{\text {motor }}$. The power output $P_{\text {out }}$ was calculated by multiplying the motor speed by the torque and by a constant,

$k\left(\tau_{\text {motor }} \omega\right)=P_{\text {out }}$

The motor efficiency was found by dividing the two power values,

$\eta_{\text {motor }}=P_{\text {out }} / P_{\text {in }}$

A family of efficiency curves was plotted based on this speed vs. torque data (Fig. 7).

In designing the driveline system, the amount of torque needed to move the car $\tau_{\text {wheel }}$ was found as the dot product of quantified resistance forces and wheel radius. This multiplied by a gear reduction $r$, yielded the motor torque

$\tau_{\text {motor }}=\tau_{\text {wheel }} r$

From the efficiency curves (Fig. 8) an optimum motor speed was found, offering a related motor torque. The above equation was balanced by varying $r$. Sunrunner's motor operated with a maximum efficiency $\eta_{\max }=90 \%$, where $\omega=2200 \mathrm{rev} \min ^{-1}$, requiring approximately $1000 \mathrm{~W}(1.34 \mathrm{hp})$ of input power. A direct drive gear ratio of 4.28:1 generated a wheel speed $v_{\text {wheel }}=59.5$ $\mathrm{km} \mathrm{h}^{-1}$ (37 miles per hour). 


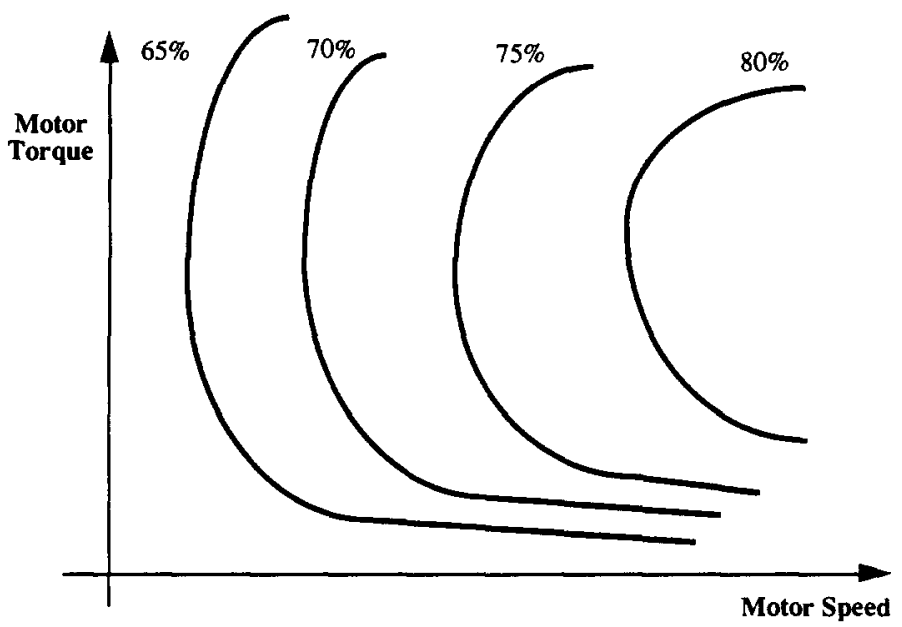

Fig. 7. Family of efficiency curves.

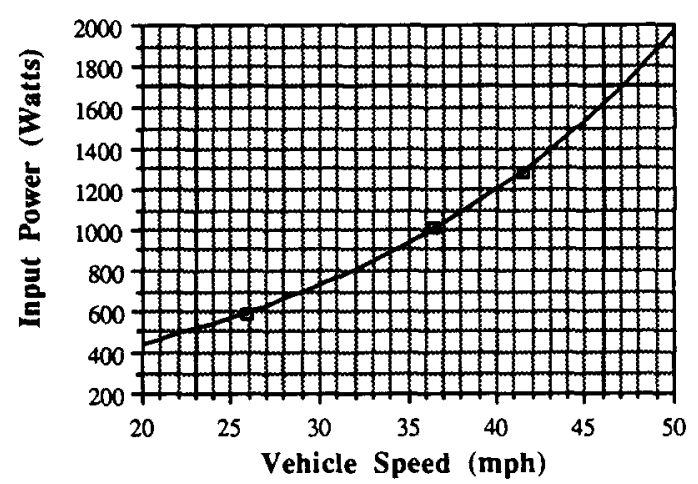

Fig. 8. Plot of power vs. speed.

\section{Chassis}

\subsection{Frame}

Sunrunner's tubular spaceframe bore static loads of subsystem components and incurred dynamic loads when in motion. Design requirements included safety considerations, light weight, ease of fabrication, reliability, and repairability.

The frame structure consisted of 67 thin-walled aluminum tubes welded at 23 nodes, weighing $15 \mathrm{~kg}(33 \mathrm{lb})$ with bracketry. Composite materials were ruled out because of the lack of weldability and availability of an epoxy for nodal adhesion with satisfactory shear strength qualities.

The frame was modelled on a finite element analysis computer program, where masses were "lumped" at different nodes representing masses of various subsystems. The total static loading equalled $224.4 \mathrm{~kg}(494 \mathrm{lb})$ and was broken down as follows. 


\begin{tabular}{lcc}
\hline Subsystem & Mass (kg (lb)) & $\begin{array}{l}\text { Nodal } \\
\text { distribution }\end{array}$ \\
\hline Batteries and power trackers & $54.4(120)$ & 2 \\
Body shell & $56.7(125)$ & 9 \\
Driver, seat and restraints & $88.2(194)$ & 4 \\
Motor and driveline & $7.0(15)$ & 2 \\
Solar cells & $18.1(40)$ & 2 \\
\hline
\end{tabular}

Dynamic driving and safety conditions were simulated, under nine loadcases, by placing forces axially on frame members. Each member was checked for buckling or yielding. The loadcases included still static loading, cornering loading, braking force, combined cornering and braking, twist bump force, jacking torsion force, towing force, simulated roll analysis, and side impact analysis.

Under still static loading, the frame was constrained at the wheels, suspension links were modelled as rigid elements, and one force of gravity ( $1 \mathrm{G}$ ) was exerted on the lumped masses. This case ensured that the frame would support its own weight, although the solar car would never experience a $1 \mathrm{G}$ acceleration. For the twist bump force, the front right and rear left wheels were constrained, as a vertical downward acceleration of $4 \mathrm{G}$ was placed on lumped masses, simulating a torsion bump. Under simulated roll analysis, the frame was constrained at the top two nodes and an upward 4 $\mathrm{G}$ acceleration excited the lumped masses. This case rated the stability of the frame for rollover occupancy protection. In side impact analysis, the frame was sandwiched, as $454.5 \mathrm{~kg}(1000 \mathrm{lb})$ nodal forces were applied to each side of the frame, testing occupant protection from the sides.

From the analysis, frame member forces were extracted and used to calculate maximum stresses, which were compared with yield strength and critical buckling stresses, offering the following results:

\begin{tabular}{lcll}
\hline Loadcase & $\begin{array}{l}\text { Element } \\
\text { stress }(\mathrm{MPa})\end{array}$ & $\begin{array}{l}\text { Nodal } \\
\text { displacement (mm) }\end{array}$ & Buckling \\
\hline 1 G still static loading & 13.23 & 0.38 & No \\
4 G twist bump force & 62.44 & 2.39 & No \\
4 G roll analysis & 131.43 & 2.89 & No \\
Side impact & 61.01 & 1.41 & No \\
\hline
\end{tabular}

\subsection{Front suspension (Fig. 9)}

Concerns regarding packaging a front suspension within body sidepods led to considerations of a double A-arm suspension and MacPherson strut. Because A-arms would have been exposed and the aerodynamics affected, the final design was a modified MacPherson strut, where a $70 \mathrm{lb} \mathrm{inch}^{-1}$ spring fit over a gas-charged damper. The damper was inserted into a tubular housing, to the bottom of which a bearing housing was welded. The lower spring seat, outer steering arm, transverse link ring, and brake mounts were 


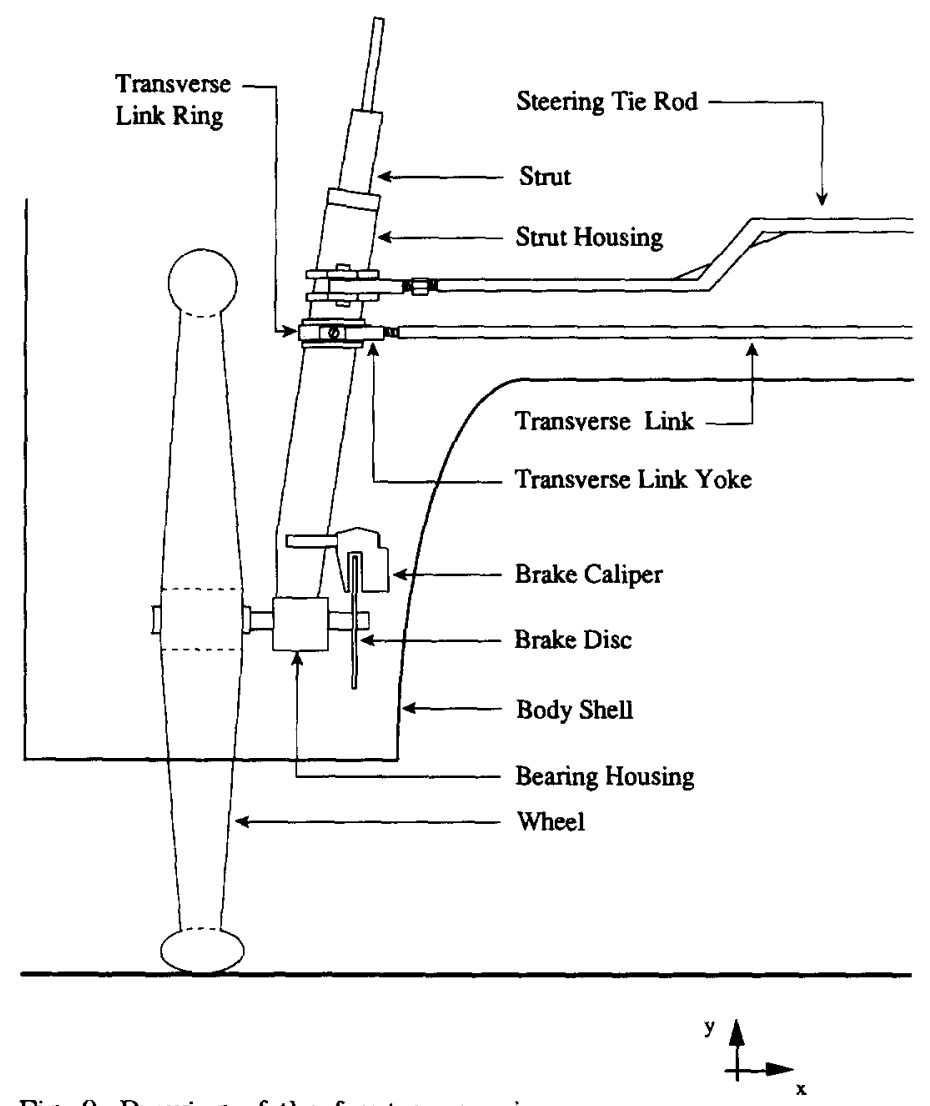

Fig. 9. Drawing of the front suspension.

connected to the strut housing. The outer steering arm attached to the steering tie rod by means of a female rod end. Toe-in and toe-out were controlled by adjusting a hexagonal stud, the ends of which were threaded in opposite directions. The bent tie rods were hooked to inner steering arms, which bolted into the rack and pinion. The split transverse link ring rotated about the strut tube and was attached to a U-shaped yoke, through which a stud threaded into the transverse link. The transverse link connected to a frame node in the center of the car directly below the steering wheel. Brake mounts were welded to the strut housing, holding a hydraulic caliper. The bearing housing contained plane bearings through which the axle was inserted. At the bottom of the bearing housings a stud was welded, over which a high-displacement male rod end was attached, threaded into the leading link, regulating $5^{\circ}$ of caster. The leading link attached to brackets in the frame's rear.

Initially the strut angle $\phi$ was designed at $15^{\circ}$ from the vertical. This allowed $6.35 \mathrm{~mm}(0.25 \mathrm{inch})$ of outboard steering offset, ensuring that the front wheels would self center during braking. However, owing to body pitching for aerodynamics and packaging constraints, the strut angle was 
changed to $8^{\circ}$, forcing a 0.75 inch inboard steering offset. Extensive testing revealed that this geometry change did not affect overall vehicle handling, although the wheels did not self center during braking.

The transverse links, leading links, and strut tubes, were designed to withstand maximum axial loads and bending moments, derived from most extreme accelerations and loadings.

\subsection{Rear suspension}

Rear suspension design constraints included packaging, light weight, and reliability under $1 \mathrm{G}$ comering and $4 \mathrm{G}$ twist bump conditions. Initially, to avoid suspension links protruding from the body shell parallel to the ground, a fork-type suspension was considered. However, inability to withstand bending moments generated during expected lateral motion ruled out this option. The end choice was a modified trailing arm system where at one end the arms were attached to the chassis with spherical rod ends, and at the other they came together and were welded to a bearing housing. A coil-over shock absorber providing springing and damping was mounted on the top of the bearing housing. The final spring rate was $50 \mathrm{lb}_{\text {inch }}^{-1}$ with an average motion ratio $\left(\Delta_{\text {wheel }} / \Delta_{\text {spring }}\right)$ of 1.01 .

\subsection{Axles, wheels and tires}

Axles were designed based on vehicle weight and projected road inputs. On one side of the bearing housing a double spline system was used; a cross flange, with inner bore female splines fastened with a friction fit over a section of the axle with extruding splines. The wheel hub was then coupled to the outside of the cross flange. On the other side of the bearing housing a brake flange slid over intruding axle splines and bolted to a rotating brake disk.

Axles were designed under worst case conditions that included a $2.6 \mathrm{G}$ vertical acceleration for road bumps, a $0.7 \mathrm{G}$ horizontal acceleration for extreme turning conditions, and a full caliper brake torque on the disk. A computer program was written to determine principal axle stresses with these acceleration inputs.

The axles fit through the wheel hub which was strong enough to withstand stresses of spokes, yet soft enough to allow them to seat properly. A compromise was found in dimensioning the hub, as its length was directly relative to lateral strength and inversely relative to its normal strength. All terrain bicycle wheels are attached with straight spokes, which can withstand higher strain per unit force than the double-butted type. Ability to withstand strain minimized lateral wheel deflection, which prevented the wheels from coming out of alignment.

Bald mountain bike tires with low rolling resistance fit over the rims, and the entire assembly was tested. With the axle perpendicular to the ground, $29.9 \mathrm{~N}(216 \mathrm{lb})$ were hung from the rim end, and a plastic deformation of $1.5 \mathrm{~mm}(0.060 \mathrm{inch})$ was noted. $62.3 \mathrm{~N}(450 \mathrm{lb})$ was then placed on a 
wheel, with the axle parallel to the ground. Here, no elastic deformation was observed.

\subsection{Brakes}

GM Sunrayce USA regulated that brakes must be able to achieve a 0.43 $\mathrm{G}$ stopping deceleration. Initially, cable actuated calipers were installed; however, unsatisfactory performance led to a hydraulic system, offering 0.51 G. The 5 inch bolts went through the floating calipers into unthreaded holes in the brake mounts.

\subsection{Steering}

The steering system consisted of a rack and pinion, attaching to an inner steering arm which connected to the outer steering arm by means of the tie rod. A sprocket was threaded to the rack encasement and was connected to another sprocket threaded to the steering column. The steering wheel rotated the column sprocket, allowing for vehicle manipulation.

In designing the steering system, the objectives were to incorporate "Ackerman steering", and to avoid "bump steer". Ackerman steering minimizes frictional energy loss, or "tire scrub", when turning. Here, the outside wheel actually turns less than the inside wheel, allowing lines perpendicular to the center of each wheel to extend to a point called the "Ackerman center". Also passing through this point is a line which intersects the rear wheel axles perpendicularly. It was designed into the system when lines from the outer steering arms were brought to a point which fell exactly in between the rear wheels.

To avoid bump steer, suspension pivot points must move exactly like steering pivot points. By designing both sets of pivot points to fall in the same horizontal plane, bumpy roads would not induce Sunrunner self-steering.

\begin{tabular}{lllll}
\hline Part & Material & O.D. & W.T. & Function \\
\hline Spaceframe & $6061-\mathrm{T} 6 \mathrm{Al}$ & 1 & 0.049 & Bear dynamic and static loads of car \\
Strut housing & 4130 steel & 2 & 0.125 Houses strut insert \\
Leading link & $3 \mathrm{Al}-2.5 \mathrm{~V}-\mathrm{Ti}$ & 1 & 0.051 & Caster adjustment, bears braking forces \\
Transverse link & $3 \mathrm{Al}-2.5 \mathrm{~V}-\mathrm{Ti}$ & 0.625 & 0.042 & Camber adjustment \\
T. 1. yoke & $7075-\mathrm{T} 6 \mathrm{Al}$ & - & - & Connect strut housing to transverse link \\
Steering tie rod & 3Al-2.5V-Ti & 0.625 & 0.042 & Toe-in-toe-out adjustment, \\
Outer steering arm & 4130 steel & 0.125 & plate & Transfer turning force to wheel \\
Inner steering arm & $6061-\mathrm{T} 6 \mathrm{Al}$ & 0.125 & plate & Transfer turning force to tie rod \\
Trailing arms & $3 \mathrm{Al}-2.5 \mathrm{~V}-\mathrm{Ti}$ & 1 & 0.051 & Rear suspension \\
Rack and pinion & $6 \mathrm{Al}-4 \mathrm{~V}-\mathrm{Ti}$ & - & - & Transfer turning force to inner arm \\
Brake disk & $7075-\mathrm{T} 6 \mathrm{Al}$ & 6 inch plate & $\mathbf{0 . 1 2 5}$ & Rotate at wheel rev min \\
Wheel hubs & $2124 \mathrm{Al}$ & - & - & Support wheels \\
Axles & $6 \mathrm{Al}-4 \mathrm{~V}-\mathrm{Ti}$ & 0.669 & - & Support wheels \\
Wheels & $6061 \mathrm{Al}$ & 26.0 & - & Support vehicle \\
\hline
\end{tabular}

